\title{
Chapter 3 \\ Local Educational Landscapes in Germany: Interfaces and Interlacings Between Education and Urban Development
}

\author{
Thomas Coelen, Anna J. Heinrich, and Angela Million
}

\section{Introduction}

For some years now, experts and policymakers in Germany have been discussing how local educational infrastructure can be developed into local educational landscapes, and they are increasingly coming to the conclusion that issues around child raising, care, and local education (all-day schools and childcare centers) can no longer be dealt with separately from problems related to urban development (e.g., marginalized neighborhoods, site redevelopment). Although the discourses and practices of those working in education and social affairs have long run parallel to those in urban development, initial experience gathered in practice is increasingly being drawn upon to test out integrated approaches and model projects (e.g., Bildungsoffensive Elbinseln in Hamburg, Bildungsverbund Gropiusstadt in Berlin; for more detail, see Burgdorff \& Herrmann-Lobreyer, 2010). Both educators and planners engaging in theoretical discourse on the subject are showing signs of an increased interest in the mutual relationship between education and urban development (e.g., Coelen, Heinrich, \& Million, 2015, 2016; Kessl \& Reutlinger, 2013a; Million, Heinrich, \& Coelen, 2017; Reutlinger, 2009). For a long time, however, the flow of ideas between the two disciplines was restricted to a dialogue on terminology; until now, there has been a lack of empirical research viewing education and urban development as two systematically related processes (examples are Böhme, 2009; Kessl \& Reutlinger, 2013b, p. 7; Westphal, 2007).

\footnotetext{
T. Coelen $(\triangle)$

Department of Educational Sciences and Psychology, University of Siegen, Siegen, Germany e-mail: coelen@erz-wiss.uni-siegen.de
}
A. J. Heinrich · A. Million
Institute for Urban and Regional Planning (ISR), Urban Development and Settlements, Technical University Berlin, Berlin, Germany
e-mail: anna.j.heinrich@tu-berlin.de; a.million@isr.tu-berlin.de 
In view of this, the Siegen Centre for Socio-Scientific Educational Research (SiZe) has been running a DFG ${ }^{1}$-funded research project on this subject since October 2014, in association with the Institute of Urban and Regional Planning (Technical University Berlin). In a study titled "Local Educational Landscapes and Urban Development: Interfaces and Interlacings," the interdisciplinary team of researchers are investigating how education and urban development are connected spatially and in terms of content. Their investigation is based on the concept of local educational landscapes (as a currently prominent example of an interface between education and urban development), aiming to pinpoint the potentials and limits of coordinating the fields of education and urban development, and helping to systematically reconstruct and contextualize the links between the two fields-links which are frequently said to be positive but which have as yet received little verification. This contribution studies the current German debate on the interplay between education and urban development, focusing on the concept of local educational landscapes to offer an insight into the above research project, along with some initial empirical findings.

\section{The Relationship Between Education, Space and Urban Development}

Researchers increasingly believe that the fields of education and urban development have relevant effects upon one another (Tibussek, 2012, p. 7). This can be described with two theses:

The thesis "urban development is of educational relevance" (Tibussek, 2012, p. 7) proposes that urban development should have an enabling component, because it directly and indirectly influences the development and transformation of educational settings in the urban space (Million, Heinrich, \& Coelen, 2015a, p. 2; Tibussek, 2012, p. 7). Educational processes of children and young people are embedded in the urban space. According to this thesis, the neighborhood, district, and city as a whole serve more than a residential purpose. Rather, neighborhoods, districts and city quarters with their manifold educational settings form the basic framework of educational processes. Thus, urban space can also be interpreted as a learning experience (Mack, 2008, pp. 743-744). Depending on how the urban space is created and structured, it can enable or restrict the opportunities of individual educational processes (Deinet, 2008, p. 727; Nonnenmacher, 2015, pp. 138-139). Therefore, processes of creating the urban space as a varied learning experience are related to questions of urban development and urban planning (Mack, 2008, p. 744). The extent to which urban space enables educational processes depends on the processes by which urban development comes about.

\footnotetext{
${ }^{1}$ This abbreviation stands for "Deutsche Forschungsgemeinschaft" (German Research Foundation).
} 
The thesis "education is relevant to urban development" (Tibussek, 2012, p. 8) emphasizes the importance of education for a sustainable and integrative development of districts and of the city as a whole. At the level of communal policy, especially, education has transformed from a weak into a strong locational factor for urban development (Deutscher Städtetag, 2007; Hebborn, 2011, p. 140) and has become an essential component of good urban development (Burgdorff \& Herrmann-Lobreyer, 2010; Coelen et al., 2015). Researchers discuss the relevance of education to urban development processes from various viewpoints: The further development and conversion of a quarter's educational infrastructure might have an effect on shaping good educational opportunities in the urban space and therefore serve as a starting point for preventing educational inequality. It could also prevent the resulting social costs (e.g., increasing social transfer payments), which are caused by failed individual educational biographies and employment histories (Meier, 2008, p. 15; Olk, Somborski, \& Stimpel, 2011, p. 155). Furthermore, joint efforts in education could contribute to the social and economic stabilization and general improvement of the quarter (Biernath et al., 2009, pp. 2-3; Coelen et al., 2016, pp. 145-146). Keywords for this are social desegregation, a higher quality of urban living, social integration, and economic uptrend.

From this point of view, in the context of urban development, schools are gaining particular importance as the central focus of community life in neighborhoods and districts. It is assumed that schools work as a mechanism for sociospatial segregation, because families who value education often consider schools decisive when establishing their place of residence (Häußermann, 2002, pp. 78-79; Merkle \& Wippermann, 2008). These mostly high-income families want the best schools for their children. However, this means that the implementation of good-quality schools in so-called socially deprived districts might counteract social segregation and promote the improvement of sociocultural life in these quarters by attracting households with an interest in education (Baumheier \& Warsewa, 2009, p. 21; Häußermann, 2002, pp. 78-79).

The prospective of the two areas of practice-education and urban developmentbeing connected is coming to the foreground in debates on local educational landscapes, as a currently prominent example of a touch point between education and urban development. This touch point is at the focus of the empirical work in the above research project and will be outlined in more detail below.

\section{Local Educational Landscapes as an Interface Between Education and Urban Development}

In the sociopolitical debate on "up-to-date education," the significance of the world in which people live and learn-municipal or urban spaces—-has risen significantly in recent years. Since the 1990s, there has been a trend towards municipalizing education 
(Weiß, 2011), expressed in various concepts and programs on federal and regional policy levels (e.g., the "Semi-Autonomous Schools project" 2002-2008; the "Selbständige Schule" project, 2004) and various funding programs organized by the EU and the federal government (e.g., "Learning Regions-Providing Support for Networks," BMBF/ESF, 2000-2008; "Learning Locally," BMBF/ESF, 2009-2014) (Million, Heinrich, \& Coelen, 2015b, p. 5; Olk \& Stimpel, 2011, pp. 169-170). This generally includes the development that local regional authorities (municipalities, rural districts) are increasingly being given greater responsibility for educational coordination and management (Deutscher Städtetag, 2007, 2012). This paradigm shift comes from increasing requirements made of municipalities as a result of changes in social structure (demographic change, globalized economic processes). The municipalities are concerned that current challenges such as the polarization of social spaces and related tendencies towards the spatialization of social inequality or social disintegration could have a negative effect on cities' social makeup, local competitiveness, and future economic development. This is one reason why experts generally see a functioning education system and well qualified citizens as key factors. Education is becoming a central pull factor for municipalities. However, as the federal states are in fact responsible for shaping the education system under constitutional law, processes of educational municipalization imply a call for municipalities to be given greater powers to shape the education system if they are to have a more active, formative influence on local educational development (Hebborn, 2011, pp. 152-154).

From the point of view of educational policy, the discussion on local educational landscapes in Germany can also be seen as an extension of the PISA debate to include the increase in the number of full-service community schools and the development of a coordinated system of education, childcare, and child raising. The plan put forward involved the local coordination of all institutions and schemes involved in processes of formal and informal education. This would extend the scope from classic educational institutions (such as schools) to include all local educational activities and promote an understanding of city or urban spaces as a space for education (BMFSFJ, 2005, pp. 31-32; Mack, 2008). In view of this, the subject is not only relevant for education, but is also turning into a field of discussion and action among urban developers and planners.

\section{The Current State of the German Debate on Local Educational Landscapes}

In recent years, practitioners' and policymakers' calls for innovative pedagogical approaches to achieve more equal opportunity education for all have almost all been answered with the concept of local educational landscapes.

However, the professional discourse has yet to come up with a satisfactory definition of what is currently meant by a local educational landscape (Mattern \& Lindner, 2015, p. 82). Working definitions have been established as an initial means 
of access to the concept: For example, Bleckmann and Durdel (2009, p. 12) $)^{2}$ understand local educational landscapes as "long-term, professional education networks formed through municipal policy to follow joint plans for learning from the standpoint of the subject, including formal and informal learning environments and related to a defined locality." Bringing together all previous attempts to describe the concept, Mattern and Lindner (2015, p. 82) see local educational landscapes as "a small, defined conglomerate of actors of all kinds, joined in any form ..., trying in unison, as an interconnected system, to institutionalize what can very generally be described as "education."”

The institutionalization of this kind of education system is linked to a wide range of intended goals. Generally, the concept is based on the idea of helping to promote education and iron out inequalities caused by education by introducing integrated educational opportunities and linking various educational establishments and actors locally, within a social space (Berse, 2009, p. 205; Bleckmann, 2012, p. 290; Mattern \& Lindner, 2015, pp. 87-88). Other expectations linked to the term local educational landscape include close interconnections between schools and the youth welfare services, bringing actors from outside the professional field (companies, foundations, etc.) into the social welfare and education system, or renegotiating municipal responsibilities for the field of education (Hebborn, 2011).

Within the debate on education and educational science, efforts are being made to link the concept to pre-existing conceptual approaches such as all-day schooling (Bleckmann \& Durdel, 2009; Coelen, 2009; Stolz, 2009), cooperation between the youth welfare services and schools (e.g., Maykus, 2009), and the concept of appropriation (Deinet, 2015), or to question the validity of organizational and regulatory structures in the context of local educational landscapes (e.g., Lindner, Niedlich, Klausing, \& Brüsemeister, 2015a, 2015b; Olk \& Stimpel, 2011; Tibussek, 2009). Furthermore, findings from accompanying projects are making their way into the discourse on practical implementation within municipalities (e.g., Kucharz, Bohl, Eisnach, Fink, \& Müller, 2009; Olk, 2015), or to support programs (such as the "Learning Locally" program) aimed at establishing the concept (Lindner et al., 2015a, 2015b). Spatial theorists are also increasingly interested in the concept; they mainly discuss local educational landscapes from the point of view of education as a strategy for sustainable urban and district development, or as a component of urban or regional space (e.g., Reutlinger, 2011; Tibussek, 2015). An interdisciplinary anthology by Coelen et al. (2015) ${ }^{3}$ describes the current status of the debate on interfaces between the education system and urban development.

Only recently have some researchers also attempted to adopt a critical stance towards the concept of educational landscapes. For example, some have pointed out that the discussion has avoided fundamental pedagogical and conceptual questions on how formal and informal education processes can be linked, that the concept shows signs of being limited to formal education settings (schools, daycare institutions) (Stolz, 2012, pp. 29-30), and that any critical reflection on local

${ }^{2}$ The term has also been described by others such as Coelen and Croonenbroeck (2011, pp. 338-339).

${ }^{3}$ See also Million et al. (2017). 
educational landscapes as a postulated answer to current processes of social change is as of yet lacking (Mattern \& Lindner, 2015, pp. 86-87).

\section{The National State of Research on Local Educational Landscapes}

Despite increased research into local educational landscapes in recent years, discussion within the German debate on local educational landscapes has so far mainly been characterized by basic programmatic or normative issues, well meant statements of intent by municipal policymakers, or best-practice examples (e.g., Bleckmann \& Durdel, 2009; Bleckmann \& Schmidt, 2012; Bollweg \& Otto, 2011), rather than by research-based work on empirical studies or findings. Initial accompanying studies and evaluations of federal and regional funding programs (e.g., DKJS, 2012a, 2012b; Huber, Kilic, Schwander, \& Wolfgramm, 2014; Meinecke, Schalkhaußer, \& Täubig, 2009; Projektleitung "Selbständige Schule," 2004; Stolz, 2008; Tippelt, Dobischat, Hagen, \& Nuissl von Rhein, 2006) have provided some initial ideas and indications of what causes municipal educational landscapes to succeed or fail. Other national studies on local educational landscapes have mainly shed light on potentials, cooperative work, and cooperative networks in and around school networks or local educational landscapes, and the organizational structures within them (e.g., Berkemeyer \& Bos, 2010; Berkemeyer, Kuper, Manitius, \& Müthing, 2009; Huber, 2014a, 2014b; Huber, Ahlgrimm, \& Hader-Popp, 2012; Lindner et al., 2015a, 2015b; Niemann, 2014; Olk, 2015). Not until recently has the empirical spotlight also been shone on the users of local educational landscapes (e.g., Wüstenrot Stiftung, 2015).

Following Berse (2009), the state of research and practice regarding cooperation between the child and youth welfare services and schools or local educational landscapes can be summed up under four types of local educational landscapes: (1) cooperation between the youth welfare services and schools, (2) schools and the how they are improved, (3) lifelong learning, continuing education, and business, (4) social spaces as educational spaces (see Berse, 2009, p. 198).

Maykus $(2009$, pp. 49, 53) points to the urgent need for research into local educational landscapes, including their conditionality on context (e.g., the social space, municipality, region). Current research work on local educational landscapes has, however, rarely explicitly addressed educational associations focusing on shaping living conditions within social spaces as a basis for educational processes (Berse, 2009 , p. 202) while also looking into the role played by aspects related to social spaces or urban development (e.g., Kessl \& Reutlinger, 2013a; Olk \& Somborski, 2013; Olk \& Woide, 2014).

As work has only just begun on developing theories and carrying out empirical investigations on local educational landscapes in the context of urban development, the state of the research on this matter is generally lacking, and there is an ongoing need for research, which the research project "Local educational landscapes and urban development," among others, is intended to meet. 


\section{The State of Scientific Research in the Field of Educational Landscapes on a European Level}

In many European countries, a discourse is being held between politics and academia which is increasingly taking up the subjects of economic, educational, and social policy (e.g., related to social spaces) (Butler \& Hamnett, 2007, p. 1162; Du Bois-Reymond, 2011, pp. 518, 525). In the EU, for example, efforts are being made to introduce binding, unified standards in the field of education (e.g., Europäische Kommission, 2008). However, education is not (yet) being discussed at the EU level as a matter of urban policy (Du Bois-Reymond, 2011, p. 531). International examples similar to the concept of local educational landscape with a link to social spaces are being implemented in some European countries: The brede scholen are a kind of full-service community school being introduced at the primary level in the Netherlands, planned as a networked school with links to the neighborhood ( Du Bois-Reymond, 2011, pp. 519-521). The British concept of extended schools plans for an extensive range of full-service community schools also directed at the neighborhood (Coelen, 2009; Otto \& Coelen, 2005). Comparable projects are being carried out in practice in Switzerland and Austria (e.g., the Vienna Education Campus). Nonetheless, local educational landscapes are a very new field of action and discussion, even internationally (Heers, van Klaveren, Groot, \& Maassen van den Brink, 2011, p. 17). Initial studies on educational landscapes in Britain and the Netherlands indicate that there is a positive connection between education and urban development. Cooperative schemes involving schools and external partners have positive effects on attendance and individual learning performance, among other things (Baumheier \& Warsewa, 2009, p. 15; Heers et al., 2011, p. 6). As a whole, though, even in other European countries there is a need for empirical research on educational associations and their effects (e.g., on urban spaces) (Heers et al., 2011, pp. 2, 18).

\section{The Research Project "Local Educational Landscapes and Urban Development: Interfaces and Interlacings"}

The research project "Local Educational Landscapes and Urban DevelopmentInterfaces and Interlacings" uses a qualitative investigative design to study conceptual and practical connections and relations between contextual and spatial aspects of education and urban development in theory and practice at different scales (federal, regional, municipal). Its investigation of the link between education and urban development at the municipal level is grounded in the concept of local educational landscapes, as a currently prominent example of education meeting urban development. The focus is on local educational landscapes specifically aimed at "social spaces as educational spaces" (Berse, 2009, p. 198). The central lines of questioning behind the investigation are as follows: 

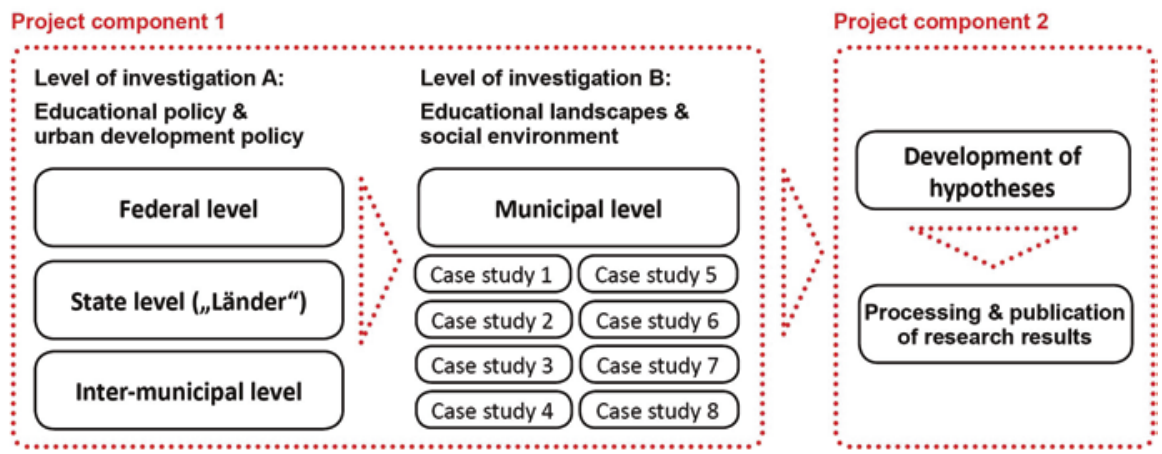

Fig. 3.1 Overview of the research project structure. Source: Design by author

- What contextual and spatial interfaces and interlacings exist between education and urban development at the federal, state, municipal, and local level?

- What meanings and significance do stakeholders in education and urban development attribute to the different common and overlapping thematic areas?

- What aims and strategies for action addressing cross-cutting issues of education and urban development are discussed within the two policy fields?

To answer these questions, the we have chosen a qualitative mixed-methods design (see Fig. 3.1) divided into two components as our methodological approach:

Project Component 1: The first phase of Project Component 1 includes empirical research on the relationship between education and urban development at different levels: federal, state, and municipal. Initially, we explore cross-sectoral lines of discussion on educational policy and urban development policy at these levels. The basis of the investigation is formed by interviews with relevant representatives of federal and state ministries and national federations of municipalities (e.g., the German Federal Ministry of Education and Research, German Federal Environment Ministry, German Association of Cities (DST)). We supplement our analysis of the interviews with an analysis of policy documents from both policy fields, such as political papers and reports and documentations of programs run by these players. We analyze the entire set of material by applying a qualitative content analysis (Mayring, 2015), which we carry out by using the policy cycle (Blum \& Schubert, 2011) as a heuristic framework. The aim of the policy analysis is to investigate policies and their principles, contents, results, and effects (Blum \& Schubert, 2011, pp. 15-16; Schneider \& Janning, 2006, pp. 32, 48). Accordingly, we take the three main stages of the policy cycle into account: (1) agenda setting, (2) policy formulation, and (3) implementation.

In the second phase of this project module, we will analyze eight examples of local educational landscapes in German cities that have a particular focus on the social and built environment. To narrow down the range of educational landscapes examined in this research project, we selected those in which social spaces act as 
educational spaces—educational landscapes "where education policy networking is based on social spaces as an educational location"-and which see "shaping the living conditions of social spaces ... as a foundation for educational processes" (Berse, 2009, p. 202).

The aim is thus to examine educational landscapes with goals related to urban spaces, those which have an effect on spaces. We have therefore searched for educational landscapes that can be characterized as follows: (1) educational networks that focus on the social space as a space for education and (2) those whose actors want to shape sociospatial conditions as a basis for educational processes. After looking at all the educational landscapes that currently exist in Germany, we found eight projects with this spatial dimension. These eight examples make up our case studies.

We chose a mixed-methods research design for these case studies, combining interviews with local experts in education and urban development (e.g., political and administrative stakeholders, deputy speakers of the local projects) with analyzing the content of relevant documents and urban planning analyses to document the spatial form taken by the educational landscapes.

Project Component 2: The second project module will include an integrated interpretation of the research results and the development of hypotheses that describe the interfaces and interlacings between education and urban development. These hypotheses will form the basis for further research.

At the current stage of the research project, initial findings are available for Project Module 1: the programmatic positions taken by federal, regional, and intermunicipal policymakers in education and urban development with regard to points where education and urban development already meet, and the importance that the two sets of policymakers ascribe to such points. We have reached our initial findings by analyzing documents and expert interviews with relevant ministers at the federal level, ministries related to the subject in three German Länder (state level), and two leading municipal organizations working at the federal level (intermunicipal level).

\section{Initial Findings of the Research Project}

A central topos at the administrative interface between education and urban development policy at the federal, state, and intermunicipal level is what is known as socially deprived districts. One aspect that interviewees saw as important was the widening social rift and increasing segregation (especially in German cities) leading to growing differences in the social structure of the population in each urban setting. Policymakers at the federal, state, and intermunicipal level are concerned that this may be closely related to downhill trends in individual districts, or even to neighborhoods losing their function. As a result, considerably worse social problems then cumulate and gather in these neighborhoods than in other districts (e.g., longterm unemployment, the threat of poverty, etc.), accompanied by disintegrating structures (e.g., poor quality of urban life, lack of investment in building renovation, weak infrastructure, lack of employment opportunities), "which then frequently 
gives the neighborhood a generally neglected appearance" (officeholder in the field of urban development). This cumulation can, in turn, negatively affect the living situation of the families and children residing there; for example, families may lack the financial resources to individually invest in education or high-quality educational institutions to make up for the deficit.

In conclusion, negative long-term effects on the individual (e.g., educational biographies which have gone wrong, resulting in occupational and social exclusion) and the social cohesion of the city (e.g., processes of sociospatial segregation and polarization, tendencies for social inequalities to be spatialized) are associated with socially deprived quarters. This creates a new pressure for political action in both political fields and leads to socially disadvantaged neighborhoods being prioritized as target areas requiring preferential treatment through strategies and funding programs.

And then we also had a priority, the social trouble spot-that's where we did it first. So, there was actually an order in terms of urban development policy. (officeholder in the field of education)

The overriding aim is to fund and provide resources to disadvantaged districts and thus the people living there. However, one could criticize that this spatializes social problems, turning them into spatial problems (Belina, 2006, p. 26). The neighborhoods where social cartographers identify social problems and unfavorable urban situations (criminality, etc.) are turned, so to speak, into the territorial starting point for implementing what are intended to be precisely tailored intervention strategies. In other words, the intention is to deal with challenges where they occur, or where they can be localized. In some ways, this thus combines the level on which social problems are manifested with that on which they are resolved (Kessl \& Reutlinger, 2010, p. 122). In this context, it therefore becomes extremely important to take into account and reflect upon mechanisms of social division that promote selection and exclusion, and which originate at a supralocal level (e.g., selective mobility among wealthier households).

The federal and regional ministries for education and urban development see education and schools as a segregation mechanism that has both social and spatial effects, as households that are interested in education (usually those with greater purchasing power) frequently use local opportunities for schooling and education as a criterion for choosing where to live, at least when their own children reach school age. This encourages processes of social separation and polarization, as a result of which those households with fewer educational resources tend to be left living in marginalized neighborhoods. It is therefore unsurprising that at the federal, state, and intermunicipal levels, policymakers view investments in improving the quality of the local educational infrastructure as a fundamental instrument for improving the sociospatial situation in socially deprived neighborhoods. Both sets of policymakers view improving the quality of the local educational structure as a means of promoting education and thus of promoting social integration.

In this context, children and young people are the main target groups at the interface of education and urban development. The central focus is on issues around children and young people having successful educational biographies. Special attention is given to children and youths living in socially deprived quarters, which nega- 
tively affect quality of life and childhood development. This is because an insufficient or nonexistent educational infrastructure reinforces educational disadvantages in certain social spaces - an infrastructure that lacks places for people to communicate and meet that would encourage learning, or organizations such as clubs, child and youth welfare institutions, or public and private educational establishments promoting personal development. In this context, key questions about the intersection of education and urban development ones like these posed by an officeholder at the intermunicipal level: "Where do the children live? Where are most of the children in the city born? Which districts are home to the children who are in particular need of support as their situation in life is precarious?" This adds a territorial aspect to promoting children's opportunities for education and participation, in that the place children live is used to draw conclusions about the likely problems, needs, and corresponding support they could be given. The central idea is that their opportunities for education and participation should not depend on the neighborhood where they live and grow up, expressed as follows by an officeholder on the intermunicipal level: "[W]herever I live, there is a certain equality of opportunity ... and ... that equality of opportunity does not depend on the neighborhood where I live."

On the other hand, young people who do not have a good education or training are also seen as a potential encumbrance on neighborhoods and municipalities, as education and employment biographies that have gone wrong may result in costs (e.g., social costs) for the municipalities (e.g., rising transfer payments, a rise in the unemployment rate).

Thus, the strategy of improving the quality of the local educational infrastructure aims at promoting equal educational opportunities for all children and young people. The central aim of both educational and urban development policy is to create a good environment for children and young people to live and be educated, thereby helping to achieve fair equality of opportunity.

Although the overall concept of Lifelong Learning is established both nationally and internationally, adults and older people play only a marginal role at the interface between education and urban development.

Another programmatic aim of both political fields is to stabilize and upgrade socially deprived quarters by improving the conditions of educational processes and settings in the urban space. This involves education-related measures that are suited to reducing existing disparities between neighborhoods or to reversing processes of sociospatial segregation. Actors of both policy fields postulate sociospatial educational support as a fixed element of integrated urban development strategies.

In conclusion, actors in both political fields select a territorial approach for dealing with current sociopolitical problems (social segregation, socially deprived quarters, educationally disadvantaged people).

At the interface of education and urban development policy, schools, which are usually formal educational institutions, are the central starting point for improving the quality of the local educational infrastructure. As well as improving the quality of schools, this also encompasses aspects related to the spatial/structural features of school buildings and rooms and how they relate to the success of pedagogical processes (space as a "third educator;" Beek, 2001, p. 197; Dreier, 2004, p. 137; Reggio Children, 2002, p. 40). 
Even though the implementation strategies still lack a more encompassing approach, the school's position is evidently being improved. ${ }^{4}$ Considering that schools, as formal educational institutions, are allocated a central status in modern society, this is not entirely surprising. Every debate on educational reform starts and ends with schools, and there is no denying that schools play a key role in how children and young people gain skills and grow up (see also Rauschenbach, 2007, pp. 440-442). In the context of urban development, so the argument goes on the level of federal and regional policy, schools are the new central spots of many areas- "the most important cultural centers" in the neighborhood, according to an officeholder in the field of urban development. One interviewee makes this clear as follows:

Frequently, the school is the only public institution left in a neighborhood of this kind. I mean, lots of neighborhoods don't have any community centers or any other gathering places to use, apart from schools. They [schools] are actually increasingly becoming a place for people in the neighborhood to meet up. (officeholder in the field of urban development)

Developments such as local shops or churches shrinking in size or being lost entirely mean that people are turning to schools as what is usually the only infrastructural establishment in the neighborhood, or the one that is easiest to manage. Schools are consequently seen both as a component of the city and as central educational institutions. It can thus be said that schools (and school buildings) are gaining a new and special status as key actors in the discussion on education as a component of urban development and on the level of policy and administration on education and urban development.

This can also be seen from the fact that discussions on improving the quality of local education often prioritize the implementation of all-day schools cooperating with various, usually nonformal educational institutions. Accordingly, at the point where educational and urban development policies meet, the (all-day) school acts as a sphere of action where the two fields operate simultaneously (the only other such sphere, if any, being institutions providing early-years education). The school thus plays a dominant role in education policy work and now also in urban development activities.

One aspect undermining this development, at least on the level of federal and regional policy referred to here, is the role of other education-related actors (such as child and youth welfare, social work support activities) in the field of discussion and practice around education and urban development. Although an evaluation of "Soziale Stadt," the most important German urban development funding program (since 1999) ascribed great significance to projects and activities related to the practice of district social work (e.g., promoting social infrastructure, supporting social structure, promoting culture within the district; IfS, 2004, p. 140), federal, regional, and intermunicipal policymakers within education and urban development who were questioned on the topic ascribed such actors no than a marginal role. The architectural development of the public space as an educational setting currently also seems to be of minor importance.

\footnotetext{
${ }^{4}$ The only phenomenon to shake the firmness of that position is the increasing trend towards bringing aspects of early childhood education into childcare, following the motto "education from the very start."
} 


\section{Conclusion}

Participants in the debate on local educational landscapes frequently state that there is a positive connection between education and urban development, without verifying this claim with scientific research. To this day, no recent research studies have explored the interfaces and interlacings between education and urban development. Thus, the expected outcome of our research project is a new, integrated, and interdisciplinary reflection on education and urban development in the context of local educational landscapes.

The investigation of interlacings between education and urban design is especially important in view of the sociospatial dimension of urban development as well as of education. They are intertwined with social segregation and equal opportunities in a knowledge-based society.

As this first insight into the contextual and spatial connections between educational policy and urban development in Germany at the federal, state, and municipal policy level shows, both political fields directly and indirectly deal with issues of education in the urban space. Although urban development policy and educational policy at federal and state levels share common lines of discussion (e.g., socially deprived quarters, children and young people) and have similar programmatic goals (e.g., educational equality), educational administration/policy and urban development administration/policy primarily act independently of one another and development programs and measures are only weakly coordinated. It can be assumed that interdepartmental cooperation between educational policy and urban development policy in the context of local educational landscapes will be more pronounced at the local level.

\section{References}

Baumheier, U., \& Warsewa, G. (2009). Vernetzte Bildungslandschaften: Internationale Erfahrungen und Stand der deutschen Entwicklung [Cross-linked educational landscapes: International experiences and state of the development in Germany]. In P. Bleckmann \& A. Durdel (Eds.), Lokale Bildungslandschaften: Perspektiven für Ganztagsschulen und Kommunen (pp. 19-36). Wiesbaden, Germany: VS Verlag für Sozialwissenschaften. https:// doi.org/10.1007/978-3-531-91857-0_2

Belina, B. (2006). Ordnung im städtischen Raum: Obdachlosenvertreibung und Verhinderung politischen Protests in US-Städten [Order in the urban space: Expulsion of the homeless and prevention of political protests in US cities]. Fantômas-Magazin für linke Debatte und Praxis, 9, 24-26. Retrieved from https://www.uni-frankfurt.de/45693142/2006a_Belina.pdf

Berkemeyer, N., \& Bos, W. (2010). Netzwerke als Gegenstand erziehungswissenschaftlicher Forschung [Networks as a research subject in educational sciences]. In C. Stegbauer \& R. Häußling (Eds.), Handbuch Netzwerkforschung (pp. 755-770). Wiesbaden, Germany: VS Verlag für Sozialwissenschaften. https://doi.org/10.1007/978-3-531-92575-2_66

Berkemeyer, N., Kuper, H., Manitius, V., \& Müthing, K. (2009). Schulische Vernetzung: Eine Übersicht zu aktuellen Netzwerkprojekten [Connectedness of schools: An overview of current networking projects]. Münster, Germany: Waxmann. 
Berse, C. (2009). Mehrdimensionale Bildung im Kontext Kommunaler Bildungslandschaften: Bestandsaufnahme und Perspektiven [Multidimensional education in context of municipal educational landscapes: Current state and perspectives]. Opladen, Germany: Budrich.

Biernath, A., Heußen, E., Ahnfeldt, B., von Kalben, T., Luchterhandt, D., Burgdorff, F., Gräbener, M., Herrmann, M., Holch, M., Küchel, L., Simon-Philipp, C., Steffen, G. (2009). Die Rolle der Bildung in der Nationalen Stadtentwicklungspolitik: Drei Thesen [The role of education in national urban development policy: Three theses]. Retrieved from https://www.nationalestadtentwicklungspolitik.de/NSP/SharedDocs/Downloads/DE/_Anlagen/bildung_thesen.pdf

Bleckmann, P. (2012). Lokale Bildungslandschaften: Ein Blick zurück, ein Schritt nach vorn [Local educational landscapes: A look back, a step forward]. In P. Bleckmann \& V. Schmidt (Eds.), Bildungslandschaften: Mehr Chancen für alle (pp. 283-295). Wiesbaden, Germany: VS Verlag für Sozialwissenschaften. https://doi.org/10.1007/978-3-531-94130-1_22

Bleckmann, P., \& Durdel, A. (2009). Einführung: Lokale Bildungslandschaften-die zweifache Öffnung [Introduction: Local educational landscapes—-the twofold opening]. In P. Bleckmann \& A. Durdel (Eds.), Lokale Bildungslandschaften: Perspektiven für Ganztagsschulen und Kommunen (pp. 11-16). Wiesbaden, Germany: VS Verlag für Sozialwissenschaften. https:// doi.org/10.1007/978-3-531-91857-0_1

Bleckmann, P., \& Schmidt, V. (2012). Bildungslandschaften: Mehr Chancen für alle [Educational landscapes: More opportunities for everyone]. Wiesbaden, Germany: VS Verlag für Sozialwissenschaften. https://doi.org/10.1007/978-3-531-94130-1

Blum, S., \& Schubert, K. (2011). Politikfeldanalyse [Policy analysis] (2nd ed.). Wiesbaden, Germany: VS Verlag für Sozialwissenschaften. https://doi.org/10.1007/978-3-531-92097-9

BMFSFJ (Bundesministerium für Familie, Senioren, Frauen und Jugend). (2005). Zwölfter Kinderund Jugendbericht: Bericht über die Lebenssituation junger Menschen und die Leistungen der Kinder- und Jugendhilfe in Deutschland [12th children's and youth's report: Report on the situation of live of young people and the performance of child and youth support in Germany]. Retrieved from https://www.bmfsfj.de/blob/112224/7376e6055bbcaf822ec30fc6ff72b287/12kinder-und-jugendbericht-data.pdf

Böhme, J. (2009). Raumwissenschaftliche Schul- und Bildungsforschung [Educational research in spatial science]. In J. Böhme (Ed.), Schularchitektur im interdisziplinären Diskurs: Territorialisierungskrise und Gestaltungsperspektiven des schulischen Bildungsraums (pp. 13-22). Wiesbaden, Germany: VS Verlag für Sozialwissenschaften. https://doi. org/10.1007/978-3-531-91868-6_1

Bollweg, P., \& Otto, H.-U. (2011). Räume flexibler Bildung: Bildungslandschaft in der Diskussion [Spaces of flexible education: Educational landscapes under discussion]. Sozialraumforschung und Sozialraumarbeit: Vol. 6. Wiesbaden, Germany: VS Verlag für Sozialwissenschaften.

Burgdorff, F., \& Herrmann-Lobreyer, M. (2010). Bildung im Rahmen der Nationalen Stadtentwicklungspolitik: Ausgangssituation, erste Projekte und ein gemeinsames Thesenpapier [Education in context of national urban development policy: Status quo, first projects and a joint research paper]. Informationen zur Raumentwicklung, 2/3, 143-154. Retrieved from http://www.bbsr.bund.de/BBSR/DE/Veroeffentlichungen/IzR/2010/2_3/Inhalt/ DL_BurgdorffHermannLobreyer.pdf?_blob=publicationFile\&v $=2$

Butler, T., \& Hamnett, C. (2007). The geography of education: Introduction. Urban Studies, 44, 1161-1174. https://doi.org/10.1080/00420980701329174

Coelen, T. (2009). Ganztagsbildung im Rahmen einer Kommunalen Kinder- und Jugendbildung [Full-time education in context of a municipal education of children and youth]. In P. Bleckmann \& A. Durdel (Eds.), Lokale Bildungslandschaften: Perspektiven für Ganztagsschulen und Kommunen (pp. 89-104). Wiesbaden, Germany: VS Verlag für Sozialwissenschaften. https:// doi.org/10.1007/978-3-531-91857-0_7

Coelen, T., \& Croonenbroeck, J. (2011). Innenansichten von zwei "Bildungslandschaften": Mikroperspektiven [Interior view of two "educational landscapes": microperspectives]. In P. Bollweg \& H.-U. Otto (Eds.), Räume flexibler Bildung-Bildungslandschaften in der Diskussion (pp. 337-349). Sozialraumforschung und Sozialraumarbeit: Vol. 6. Wiesbaden, Germany: VS Verlag für Sozialwissenschaften. 
Coelen, T., Heinrich, A. J., \& Million, A. (2015). Stadtbaustein Bildung [Education as a component of the city]. Wiesbaden, Germany: Springer VS. https://doi.org/10.1007/978-3-658-07314-5

Coelen, T., Heinrich, A. J., \& Million, A. (2016). Bildungslandschaften als Strategie der Stadtund Quartiersentwicklung [Educational landscapes as a strategy of urban development]. In P. Oehler, N. Thomas, \& M. Drilling (Eds.), Soziale Arbeit in der unternehmerischen Stadt: Kontexte, Programmatiken, Ausblicke (pp. 143-159). Wiesbaden, Germany: Springer VS. https://doi.org/10.1007/978-3-658-10898-4_9

Deinet, U. (2008). Sozialraumorientierung und Raumaneignung [Social space orientation and appropriation of space]. In T. Coelen \& H.-U. Otto (Eds.), Grundbegriffe Ganztagsbildung: Das Handbuch (pp. 724-731). Wiesbaden, Germany: VS Verlag für Sozialwissenschaften. https://doi.org/10.1007/978-3-531-91161-8_72

Deinet, U. (2015). Raumaneignung als Bildung im Stadtraum [Appropriation of space as education in the urban area]. In T. Coelen, A. J. Heinrich, \& A. Million (Eds.), Stadtbaustein Bildung (pp. 159165). Wiesbaden, Germany: Springer VS. https://doi.org/10.1007/978-3-658-07314-5_13

Deutscher Städtetag. (2007). Aachener Erklärung des Deutschen Städtetages anlässlich des Kongresses "Bildung in der Stadt" am 22./23. November 2007 [Declaration of Aachen of the Association of German Cites on the occasion of the congress "Education in the city" on November 22/23, 2007]. Retrieved from http://www.staedtetag.de/fachinformationen/bildung/058050/index.html

Deutscher Städtetag. (2012). Bildung gemeinsam verantworten: Münchner Erklärung des Deutschen Städtetages anlässlich des Kongresses "Bildung gemeinsam verantworten" am 8./9. November 2012 [Shared responsibility for education: Declaration of Munich of the Association of Germen cities on the occasion of the congress "Shared responsibility for education" on November 8/9, 2012]. Retrieved from http://www.staedtetag.de/imperia/md/content/ dst/muenchner_erklaerung_2012_final.pdf

DKJS (Deutsche Kinder- und Jugendstiftung gGmbH). (2012a). Das Programm Lebenswelt Schule [The programm "School as world of living"]. Retrieved from http://www.lernen-vor-ort.info/

DKJS (Deutsche Kinder- und Jugendstiftung gGmbH). (2012b). Lokale Bildungslandschaften in Kooperation von Jugendhilfe und Schule [Local educational landscapes in cooperation of youth support and school]. Retrieved from http://www.lokale-bildungslandschaften.de/fachdiskurs/forschung/dji.html

Dreier, A. (2004). Raum als dritter Erzieher [Space as a third educator]. In S. Lingenauber (Ed.), Handlexikon der Reggio-Pädagogik (pp. 135-141). Bochum, Germany: projekt.

Du Bois-Reymond, M. (2011). Bildungslandschaften in einem offenen Europa: Das Beispiel Niederlande [Educational landscapes in open Europe: The example of the Netherlands]. In P. Bollweg \& H.-U. Otto (Eds.), Räume flexibler Bildung: Bildungslandschaft in der Diskussion (pp. 519-532).Sozialraumforschung und Sozialraumarbeit: Vol. 6. Wiesbaden, Germany: VS Verlag für Sozialwissenschaften.

Europäische Kommission. (2008). Der Europäische Qualifikationsrahmen für lebenslanges Lernen [The European qualification framework for live-long learning]. Retrieved from https:// ec.europa.eu/ploteus/sites/eac-eqf/files/brochexp_de.pdf

Häußermann, H. (2002). Global, lokal, sozial: Von der Unteilbarkeit der Stadt [Global, local, social: About the indivisibility of the city]. In U. J. Walther (Ed.), Soziale Stadt-Zwischenbilanzen: Ein Programm auf dem Weg zur Sozialen Stadt? (pp. 71-85). Opladen, Germany: Leske + Budrich.

Hebborn, K. (2011). Die kommunale Bildungspolitik-Ein Entwicklungskonzept für qualitative Bildungsentwicklung, Beratung und Übergänge in den Kommunen [Local education policy—a concept of development for qualitative educational development, consulting and transitions in municipalities]. In P. Bollweg \& H.-U. Otto (Eds.), Räume flexibler Bildung: Bildungslandschaft in der Diskussion (pp. 139-155). Sozialraumforschung und Sozialraumanalyse: Vol. 6. Wiesbaden, Germany: VS Verlag für Sozialwissenschaften.

Heers, M., van Klaveren, C., Groot, W., \& van den Maassen Brink, H. (2011). Community schools unfolded: A review of the literature (Tier Working Paper Series No. TIER WP 11/04). Retrieved 
from http://www.tierweb.nl/assets/files/UM/Working\%20papers/Literature\%20Review\%20 Community\%20Schools\%20TIER\%20October\%202011.pdf

Huber, S. G. (2014a). Kooperative Bildungslandschaften: Netzwerke(n) im und mit System [Cooperative educational landscapes: Network(ing) in and with systems]. Cologne, Germany: Carl Link.

Huber, S. G. (2014b). Kooperation in Bildungslandschaften: Aktuelle Diskussionsstränge, Wirkungen und Gelingensbedingungen [Cooperation in educational landscapes: Latest threads, effects and conditions of success]. In S. G. Huber (Ed.), Kooperative Bildungslandschaften: Netzwerke(n) im und mit System (pp. 3-29). Cologne, Germany: Carl Link.

Huber, S. G., Ahlgrimm, F., \& Hader-Popp, S. (2012). Kooperation in und zwischen Schulen sowie mit anderen Bildungseinrichtungen: Aktuelle Diskussionsstränge, Wirkungen und Gelingensbedingungen [Cooperation within and between schools and other educational institutions: Latest threads, effects and conditions of success]. In S. G. Huber \& F. Ahlgrimm (Eds.), Kooperation: Aktuelle Forschung zur Kooperation in und zwischen Schulen sowie mit anderen Partnern (pp. 323-372). Münster, Germany: Waxmann.

Huber, S. G., Kilic, S., Schwander, M., \& Wolfgramm, C. (2014). Bildungslandschaften: Übersicht über exemplarische Projekte und Evaluationen [Educational landscapes: overview of illustrative projects and evaluations]. In S. G. Huber (Ed.), Kooperative Bildungslandschaften: Netzwerke(n) im und mit System (pp. 137-164). Cologne, Germany: Carl Link.

IfS (Institut für Stadtforschung und Strukturpolitik GmbH). (2004). Die Soziale Stadt: Ergebnisse der Zwischenevaluierung: Bewertung des Bund-Länder-Programms "Stadtteile mit besonderem Entwicklungsbedarf: die Soziale Stadt" nach vier Jahren Programmlaufzeit ["Die Soziale Stadt": Results of the interim survey: Evaluation of the programm "Stadtteile mit besonderem Entwicklungsbedarf: die Soziale Stadt" after a four-year term]. Retrieved from http://www.irbnet.de/daten/rswb/05039011730.pdf

Kessl, F., \& Reutlinger, C. (2010). Raumbilder: Transformierte Räumlichkeiten und deren Thematisierungsformen [Spatial imaginaries: transformed spatiality and its thematization]. In F. Kessl \& C. Reutlinger (Eds.), Sozialraum: Eine Einführung (2nd ed., pp. 75-123). Wiesbaden, Germany: VS Verlag für Sozialwissenschaften.

Kessl, F., \& Reutlinger, C. (2013a). Urbane Spielräume: Bildung und Stadtentwicklung [Urban scopes: Education and urban development]. Sozialraumforschung und Sozialraumarbeit: Vol. 8. Wiesbaden, Germany: Springer VS. https://doi.org/10.1007/978-3-531-94082-3

Kessl, F., \& Reutlinger, C. (2013b). Urbane Spielräume: Bildung und StadtentwicklungEinleitung [Urban scopes: Education and urban development-introduction]. In F. Kessl \& C. Reutlinger (Eds.), Urbane Spielräume: Bildung und Stadtentwicklung (pp. 7-16). Sozialraumforschung und Sozialraumarbeit: Vol. 8. Wiesbaden, Germany: Springer VS. https://doi.org/10.1007/978-3-531-94082-3_1

Kucharz, D., Bohl, T., Eisnach, K., Fink, C., \& Müller, C. (2009). Evaluation einer Bildungslandschaft: Eine Studie zur Entwicklung und Akzeptanz der Bildungsoffensive Ulm [Evaluation of an educational landscape: A survey of the development and acceptance of the educational campaign Ulm]. Schul- und Unterrichtsforschung: Vol. 8. Baltmannsweiler, Germany: Schneider Hohengehren.

Lindner, M., Niedlich, S., Klausing, J., \& Brüsemeister, T. (2015a). Regelungsbereiche des kommunalen Bildungsmanagements im Programm "Lernen vor Ort" [The program "Learning Locally": Range of control of the education management in municipalities]. In T. Coelen, A. J. Heinrich, \& A. Million (Eds.), Stadtbaustein Bildung (pp. 283-293). Wiesbaden, Germany: Springer VS. https://doi.org/10.1007/978-3-658-07314-5_25

Lindner, M., Niedlich, S., Klausing, J., \& Brüsemeister, T. (2015b). Zum Aufbau von Arenen des Bildungsmanagements in "Lernen vor Ort" [On creating spaces of educational management in "Learning Locally"]. Journal for Educational Research Online, 7(1), 68-93. Retrieved from https://www.pedocs.de/volltexte/2015/11048/pdf/JERO_2015_1_Lindner_et_al_Zum_ Aufbau_von_Arenen.pdf

Mack, W. (2008). Bildungslandschaften [Educational landscapes]. In T. Coelen \& H.-U. Otto (Eds.), Grundbegriffe Ganztagsbildung: Das Handbuch (pp. 741-749). Wiesbaden, Germany: VS Verlag für Sozialwissenschaften. https://doi.org/10.1007/978-3-531-91161-8_74 
Mattern, P., \& Lindner, M. (2015). Warum Bildungslandschaften? Einige Überlegungen zu Form und Funktion einer eigenartigen Figur [Why educational landscapes? Some thoughts on form and function of a peculiar figure]. Widersprüche, 135(35), 81-95. Retrieved from http://www. widersprueche-zeitschrift.de/IMG/pdf/Leseprobe_135.pdf

Maykus, S. (2009). Neue Perspektiven für Kooperation: Jugendhilfe und Schule gestalten kommunale Systeme von Bildung, Betreuung und Erziehung [New perspectives for cooperation: Youth support and school shape municipal systems of education and care]. In P. Bleckmann \& A. Durdel (Eds.), Lokale Bildungslandschaften: Perspektiven für Ganztagsschulen und Kommunen (pp. 37-55). Wiesbaden, Germany: VS Verlag für Sozialwissenschaften. https:// doi.org/10.1007/978-3-531-91857-0_3

Mayring, P. (2015). Qualitative Inhaltsanalyse: Grundlagen und Techniken [Qualitative content analysis: Basic principles and techniques] (12th ed.). Weinheim, Germany: Beltz.

Meier, J. (2008). Die Bedeutung von Bildung in der Region [The regional role of education]. In C. Stern, C. Ebel, V. Schönstein, \& O. Vorndran (Eds.), Bildungsregionen gemeinsam gestalten: Erfahrungen, Erfolge, Chancen (pp. 14-17). Gütersloh, Germany: Bertelsmann.

Meinecke, A., Schalkhaußer, S., \& Täubig, V. (2009). "Stadtteil und Schule": Netzwerke der "lokalen Bildungslandschaft" Lübeck ["District and school": Networks of "local educational landscapes" Lübeck]. In N. Berkemeyer, H. Kuper, V. Manitius, \& K. Müthing (Eds.), Schulische Vernetzung: Eine Übersicht zu aktuellen Netzwerkprojekten (pp. 149-162). Münster, Germany: Waxmann.

Merkle, T., \& Wippermann, C. (2008). Eltern unter Druck: Selbstverständnisse, Befindlichkeiten und Bedürfnisse von Eltern in verschiedenen Lebenswelten: Eine sozialwissenschaftliche Untersuchung von Sinus Sociovision GmbH im Auftrag der Konrad-Adenauer-Stiftung e.V. Stuttgart [Parents under pressure: Self-conceptions, sensitives and needs in different surroundings: A sociological survey by Sinus Sociovison $\mathrm{GmbH}$ on behalf of the KonradAdenauer-Stiftung e.V. Stuttgart]. Stuttgart, Germany: Lucius \& Lucius.

Million, A., Heinrich, A. J., \& Coelen, T. (2015a). Educational landscapes and urban development: Contextual and spatial interfaces and linkages. Planning, Practice \& Research, 30, 587-601. https://doi.org/10.1080/02697459.2015.1023069

Million, A., Heinrich, A. J., \& Coelen, T. (2015b). Schnittfelder zwischen Stadtentwicklung und Bildungswesen [Intersections between urban development and education]. In T. Coelen, A. J. Heinrich, \& A. Million (Eds.), Stadtbaustein Bildung (pp. 1-19). Wiesbaden, Germany: Springer VS. https://doi.org/10.1007/978-3-658-07314-5_1

Million, A., Heinrich, A. J., \& Coelen, T. (2017). Education, space and urban planning: Education as a component of the city. Cham, Switzerland: Springer. https://doi. org/10.1007/978-3-319-38999-8

Niemann, L. (2014). Steuerung lokaler Bildungslandschaften: Räumliche und pädagogische Entwicklung am Beispiel des Projektes Altstadt Nord Köln [Governance of local educational landscapes: Spatial and educational development: The example of the project Altstadt Nord Köln]. Wiesbaden, Germany: Springer VS. https://doi.org/10.1007/978-3-658-05713-8

Nonnenmacher, A. (2015). Städtische Armutsquartiere und Bildung [Poor urban neighborhoods and education]. In T. Coelen, A. J. Heinrich, \& A. Million (Eds.), Stadtbaustein Bildung (pp. 137-145). Wiesbaden, Germany: Springer VS. https://doi. org/10.1007/978-3-658-07314-5_11

Olk, T. (2015). Bildungslandschaften und die Reduzierung sozialräumlicher Bildungsungleichheit in der Stadt [Educational landscapes and the reducing of sociospatial disparities of education in the city]. In T. Coelen, A. J. Heinrich, \& A. Million (Eds.), Stadtbaustein Bildung (pp. 243-252). Wiesbaden, Germany: Springer VS. https://doi. org/10.1007/978-3-658-07314-5_21

Olk, T., \& Somborski, I. (2013). Sozialraum-bezogene versus Biografie-begleitende Vernetzung: Dilemmata der Bildungsvernetzung in der Mannheimer Neckarstadt-West [Social environment versus biography as networking strategies: Dilemmas of educational networking in Mannheim's Neckarstadt-West]. Lehren \& Lernen, 39(10), 4-9.

Olk, T., \& Stimpel, T. (2011). Kommunale Bildungslandschaften und Educational Governance vor Ort: Bildungspolitische Reformpotenziale durch Kooperation und Vernetzung formel- 
ler und informeller Lernorte? [Municipal educational landscapes and local educational governance: Potential for reform in educational policy through cooperation and networking of formal and informal places of learning?]. In P. Bollweg \& H.-U. Otto (Eds.), Räume flexibler Bildung: Bildungslandschaft in der Diskussion (pp. 169-187). Sozialraumforschung und Sozialraumarbeit: Vol. 6. Wiesbaden, Germany: VS Verlag für Sozialwissenschaften.

Olk, T., \& Woide, C. (2014). Educational Governance vor Ort-mehr Bildungsgerechtigkeit durch "vernetzte Bildung"? [Educational governance locally_improving educational justice through "interconnected education"?]. Forum Wohnen und Stadtentwicklung, 3, 121-124. Retrieved from https://www.vhw.de/fileadmin/user_upload/08_publikationen/verbandszeitschrift/2000_2014/ PDF_Dokumente/2014/3_2014/FWS_3_2014_Educational_Governance_vor_Ort_Prof._Dr._ Thom.pdf

Olk, T., Somborski, I., \& Stimpel, T. (2011). Stadtgesellschaft macht Bildung [Urban society shapes education]. Forum Wohnen und Stadtentwicklung, 3, 155-160. Retrieved from https:// www.researchgate.net/profile/Ivanka_Somborski/publication/287632611_Stadtgesellschaft_ macht_Bildung/links/5677efa608ae0ad265c7f95a/Stadtgesellschaft-macht-Bildung.pdf

Otto, H.-U., \& Coelen, T. (2005). Ganztägige Bildungssysteme: Innovation durch Vergleich [Fullday educational systems: Innovation through comparison]. Studien zur international und interkulturell vergleichenden Erziehungswissenschaft: Vol. 5. Münster, Germany: Waxmann.

Projektleitung "Selbständige Schule." (2004). Regionale Bildungslandschaften: Grundlagen einer staatlich-kommunalen Verantwortungsgemeinschaft [Regional educational landscapes: Basic principles of a joint responsibility by state and municipality]. Troisdorf, Germany: Bildungsverlag EINS.

Rauschenbach, T. (2007). Im Schatten der formalen Bildung: Alltagsbildung als Schlüsselfrage der Zukunft [Overshadowed by formal education: Everyday education as a future key question]. Diskurs Kindheits- und Jugendforschung, 4, 439-453. Retrieved from http://www.budrichjournals.de/index.php/diskurs/article/view/217/203

Reggio Children. (2002). Hundert Sprachen hat das Kind: Das Mögliche erzählen: Kinderprojekte der städtischen Krippen und Kindergärten von Reggio-Emilia [100 languages of a child: To tell the possible: Projects of the municipal day-care facilities and kindergartens in Reggio-Emilia]. Neuwied, Germany: Luchterhand.

Reutlinger, C. (2009). Bildungslandschaften: Eine raumtheoretische Betrachtung [Educational landscapes: A spatio-theoretical perspective]. In J. Böhme (Ed.), Schularchitektur im interdisziplinären Diskurs: Territorialisierungskrise und Gestaltungsperspektiven des schulischen Bildungsraums (pp. 119-139). Wiesbaden, Germany: VS Verlag für Sozialwissenschaften. https://doi.org/10.1007/978-3-531-91868-6_8

Reutlinger, C. (2011). Bildungsorte, Bildungsräume und Bildungslandschaften im Spiegel von Ungleichheit: Kritischer Blick auf das "Räumeln" im Bildungsdiskurs [Educational places, spaces, and landscapes in the context of disparities: a critical perspective on spatial ideas in the educational discourse]. In P. Bollweg \& H.-U. Otto (Eds.), Räume flexibler Bildung: Bildungslandschaft in der Diskussion (pp. 51-69). Sozialraumforschung und Sozialraumarbeit: Vol. 6. Wiesbaden, Germany: VS Verlag für Sozialwissenschaften.

Schneider, V., \& Janning, F. (2006). Politikfeldanalyse: Akteure, Diskurse und Netzwerke in der öffentlichen Politik [Policy analysis: Actors, discourses, and networks in public policy]. Grundwissen Politik: Vol. 43. Wiesbaden, Germany: VS Verlag für Sozialwissenschaften. https://doi.org/10.1007/978-3-531-90267-8

Stolz, H.-J. (2008). Ganztagsbildung im lokalen Raum: Perspektiven der Kinder- und Jugendhilfe [Local all-day education: Perspectives on child and youth support]. Die Deutsche Schule, $100(3), 281-288$.

Stolz, H.-J. (2009). Gelingensbedingungen lokaler Bildungslandschaften: Die Perspektive der dezentrierten Ganztagsbildung [Conditions for the success of local educational landscapes: The perspective of decentralized all-day education]. In P. Bleckmann \& A. Durdel (Eds.), Lokale Bildungslandschaften: Perspektiven für Ganztagsschulen und Kommunen (pp. 105-119). Wiesbaden, Germany: VS Verlag für Sozialwissenschaften. https://doi. org/10.1007/978-3-531-91857-0_8 
Stolz, H.-J. (2012). Bildung neu denken! Kritische Anmerkungen zu aktuellen Ansätzen lokaler Bildungslandschaften und mögliche Alternativen [Rethinking education! Critical comments on current approaches of localized educational landscapes and possible alternatives]. In P. Bleckmann \& V. Schmidt (Eds.), Bildungslandschaften: Mehr Chancen für alle (pp. 21-31). Wiesbaden, Germany: Springer VS. https://doi.org/10.1007/978-3-531-94130-1_2

Tibussek, M. (2009). Netzwerkmanagement: Steuerung in Bildungslandschaften [Network management: Governance of educational landscapes]. In P. Bleckmann \& A. Durdel (Eds.), Lokale Bildungslandschaften: Perspektiven für Ganztagsschulen und Kommunen (pp. 203-219). Wiesbaden, Germany: VS Verlag für Sozialwissenschaften. https://doi. org/10.1007/978-3-531-91857-0_15

Tibussek, M. (2012). Die Stadt und ihre Kinder: Stadtentwicklung und Bildungslandschaften: Ein Fachbeitrag zum 7. Forum des Essener Forum Baukommunikation in Zusammenarbeit mit der Stiftung Bauhaus Dessau am 17./18. Mai 2011 in Dessau [The city and its children: Urban development and educational landscapes: A contribution to the 7th Essen Forum of "Baukommunikation" in cooperation with the Bauhaus Dessau Foundation 2011, May 17-18 in Dessau]. Retrieved from http://www.lokale-bildungslandschaften.de/fileadmin/bildungslandschaften/Fachdiskurs/Fachtagungen/Tibussek_Stadtentwicklung_Bildungslandschaften. pdf

Tibussek, M. (2015). Relevanz von Bildungslandschaften für Regional- und Stadtentwicklung [Relevance of educational landscapes for regional and urban development]. In T. Coelen, A. J. Heinrich, \& A. Million (Eds.), Stadtbaustein Bildung (pp. 307-317). Wiesbaden, Germany: Springer VS. https://doi.org/10.1007/978-3-658-07314-5_27

Tippelt, R., Dobischat, R., Hagen, K., \& Nuissl von Rhein, E. (2006). Regionale Bildungsnetze: Ergebnisse zur Halbzeit des Programms "Lernende Regionen-Förderung von Netzwerken" [Regional education networks: Mid-term results of the "Learning regions - supporting networks" program]. Bielefeld, Germany: Bertelsmann.

von der Beek, A. (2001). Der Raum als 3. Erzieher [Space as a third educator]. PÄD Forum, 29(3), 197-202.

Weiß, W. W. (2011). Kommunale Bildungslandschaften: Chancen, Risiken und Perspektiven [Municipal educational landscapes: Opportunities, risks and perspectives]. Weinheim, Germany: Juventa.

Westphal, K. (2007). Orte des Lernens: Beiträge zu einer Pädagogik des Raumes [Places of learning: Contributions to a pedagogy of space]. Weinheim, Germany: Juventa.

Wüstenrot Stiftung. (Ed.). (2015). Unterwegs in deutschen Bildungslandschaften [About German educational landscapes]. Ludwigsburg, Germany: Wüstenrot Stiftung.

Open Access This chapter is licensed under the terms of the Creative Commons Attribution 4.0 International License (http://creativecommons.org/licenses/by/4.0/), which permits use, sharing, adaptation, distribution and reproduction in any medium or format, as long as you give appropriate credit to the original author(s) and the source, provide a link to the Creative Commons license and indicate if changes were made.

The images or other third party material in this chapter are included in the chapter's Creative Commons license, unless indicated otherwise in a credit line to the material. If material is not included in the chapter's Creative Commons license and your intended use is not permitted by statutory regulation or exceeds the permitted use, you will need to obtain permission directly from the copyright holder.

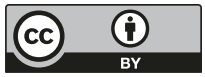

